\title{
Participation and voting in committees: Evidence from the ILO
}

\author{
Bernhard Boockmann \\ Centre for European Economic Research (ZEW) \\ P.O. Box 103443 \\ D-68034 Mannheim \\ Tel. +621 / 1235-156 \\ Fax +621/1235-225 \\ E-mail: boockmann@zew.de
}

This version: 17 March, 2004

\begin{abstract}
Although many international organisations are formally built on the principle of „one country-one vote“, a lack of representativeness in decisionmaking may give a subgroup of members disproportionate influence on the organisation's policies. Using data on participation and voting in 51 decisionmaking committees of the International Labour Organization (ILO), we do find a bias in voting outcomes due to committee composition. It has also been argued (Osborne et al., American Economic Review 2000) that voters with extreme preferences may self-select into voting committees. We suggest a procedure to test for this prediction. Controlling for characteristics, there is no indication that governments with extreme preferences are drawn disproportionately into ILO committees.
\end{abstract}

JEL-Classification: D 72, D 78, J 80

Key Words: Voting, committees, international labour standards, ILO, international organisations.

Acknowledgement: I wish to thank James F. Adams for helpful comments and the staff of the ILO Archives for support during the collection of the data. Benjamin Ohm provided excellent research assistance. This research was financially supported by the Deutsche Forschungsgemeinschaft in the framework of the research group „Institutionalization of International Negotiation Systems“. 


\section{Introduction}

In many international organisations, voting is the most important procedure for decision-making. There is, however, great diversity concerning the way member states are represented in voting decisions. Some important international organisations, such as the United Nations, are built on the principle of „one country-one vote“. Hence, in their general assemblies each country possesses the same voting weight. ${ }^{1}$ Other international organisations, such as the International Monetary Fund, give member states a quota according to their financial contributions (voting by count and account, see O'Neill and Peleg, 2000). ${ }^{2}$ Clearly, the weight with which member states are represented in decision-making depends strongly on these rules. However, it also depends on whether governments use their right to be represented in voting. In general assemblies of international organisations, participation in decision-making is often wide-spread. However, it may be highly selective at other stages of decision-making, in particular at important committees preparing decisions to be adopted by the plenary.

Participation in decision-making committees can be seen as a contribution to a public good. However, there are also private good aspects, since those represented in committees can use their voting power to further their own distributional interests. Recent theoretical research (Osborne, Rosenthal and Turner, 2000) suggests that in these settings, only extremists will participate in voting. Existing tests of the theory rely on proxies for preferences. By simultaneously explaining voting behaviour and participation, we construct a utility index based on all available observable characteristics, as well as on unobserved determinants influencing both participation and voting. The distribution of this index can then be compared between voters and nonvoters.

The empirical analysis is based on a dataset on participation and voting in 51 decision-making committees of the International Labour Organization (ILO). The ILO is based on the principle of tripartism, giving government, union and employer delegates equal weights in voting. As an empirical regularity, employer and union delegates almost always behave antagonistically

For an overview of voting in international organisations, see Zamora, 1980.

In this paper, we are not concerned with the normative implications of different voting rules; see Frey (1997) and Officer (1994). 
in committees. Therefore, governments can be ordered by the degree to which they either support one or the other side. Since all issues can be projected in the union-employer dimension of conflict, the data are unidimensional, which greatly facilitates empirical specification.

There are various accounts for the role of committees in the decisionmaking process (for reviews of the literature, see Groseclose and King, 2000, and Gerling, Grüner, Kiel and Schulte 2003). A key distinction is between informational and distributive theories of committees. Informational theories stress the role of committees to aggregate information dispersed among members of the decision-making body. A rich theoretical literature examines the properties of different decision rules and the optimal size of committees both if information acquisition is costless and costly. Gilligan and Krehbiel (1987) and Diermeier and Feddersen (2000) address the circumstances under which a committee member incurs information costs in a model where a parent chamber may overturn the committee's decision. By contrast, distributive theories start from differences in preferences regarding the outcome of the vote. Contributions starting with Weingast and Marshall (1988) consider the role of committees in stabilising log-rolls among agents in a setting where intensities of preferences differ across voters and issues. The distributive theory also comprises studies on participation in committees when participation imposes costs on voters (Bulkley, Myles and Pearson, 2001; Osborne et al., 2000). Since the distributive aspect seems to dominate the informational aspect in our application, we focus on this issue in the following.

The following section derives predictions from the theoretical literature. Section three, four and five introduce the institutions, describe how the data were obtained and present some descriptive evidence on committee voting at the ILO. In the sixth and seventh sections, we discuss the specification of the model, presenting the econometric methods and motivating the choice of explanatory variables. Results are contained in the eighth section. Section nine compares the distribution of predicted preferences between voters and non-voters. Section ten concludes. 


\section{Costly participation in voting: previous theoretical and empirical studies}

To describe the economic problem, we take it for granted that the following aspects are the most important characteristics inherent in the joint participation and voting decision.

1. Participation is costly. Delegates or their deputies (senior government officials) spend a considerable amount of time in committees. On average, the ad-hoc committees in our data last for 14 sittings, and the printed committee reports with the abstracts of discussions are sizeable volumes. Attending committee sessions is a lengthy business with presumably little intrinsic benefit.

2. Benefits are non-excludable. The outcome of the activity is a labour standard in the form of a draft treaty which ILO members may ratify. Ratification does not depend on committee membership.

3. Preferences regarding the outcome differ. Some governments (for instance, those that give a high weight to workers' interests) may be in favour of stronger standards, while others favour more weakly formulated draft treaties.

4. The outcome is decided among participants using a social choice mechanism such as majority voting.

5. The universe of voters is small. This means that, even if all eligible governments participate, each committee member has a non-negligible effect on the outcome.

To derive predictions, we need to make some more specific assumptions. First, we assume that members of the committee are interested in the outcome of the vote only. Other aspects, such as social reasons for being in the committee or reputation among states will not be considered in this paper. $^{3}$ These aspects seem to be important where voting is highly visible but less of an issue for voting in committees where voting lists are not publicly available. A second assumption is that the size of the benefit does not depend on committee members' effort. In principle, one would believe that effort is important: if members put in sufficient effort, the committee may produce a

These are considered in Boockmann (2003) for the case of public voting. 
standard that can be usefully implemented into national legal systems. If, on the other hand, members do not take their task so seriously, they may produce a defunct treaty which no country will subscribe to. Effort, such as collecting information and formulating drafts, is also a costly activity and subject to a collective good problem. However, since we are concerned with participation and not with provision of effort in committees in the empirical analysis, we neglect this issue in the following.

Properties 1 and 2 give rise to a public goods problem, and being represented in the committee is an act of voluntary provision to the public good. Provision is rational if the benefit that accrues to the individual is higher than his or her share of the costs. For instance, if actor $i$ is pivotal for the provision of the good and there is a net benefit from provision, it is rational for $i$ to participate (Dixit and Olson, 2000). Clearly, costs and benefits may be distributed unevenly among participants. Some may be more affected by the outcome of decision-making than others and, hence, be more interested in the output. Moreover, some countries incur lower costs than others, e.g. larger countries have lower costs per capita of sending an additional official to Geneva. The case of asymmetries between potential participants has long been analysed, starting with Olson and Zeckhauser (1966) who introduced a model to explain countries' contributions to international alliances.

Properties 3 and 4 introduce a conflict of interest among ILO members. A country represented in the committee does not only work together with others in order to produce a public good. It can also make the standard meet its own needs and possibly impose costs on others. Property 5 implies that the individual participation decision matters for the outcome. This distinguishes voting in committees from mass elections, where this part of the benefit would be trivial. Hence, there is a benefit from participation for actor $i$ in terms of increased utility for the voting outcome when $i$ uses its influence in decision-making.

There has been an extensive literature dealing with political participation when policies are redistributive. Extending the well-known Riker-Ordeshook (1968) model of electoral participation by strategic interaction between voters, Ledyard $(1981,1984)$ and Palfrey and Rosenthal $(1983,1985)$ derive equilibria in the participation game either under complete information or under 
incomplete information concerning other voters' costs of voting. These papers consider mass democracies where the number of voters may be high and the options for voters (such as voting for a number of candidates) are fixed. Some of the equilibria found in these studies imply a substantial turnout even if electorates are large.

Regarding participation and voting in committees, Osborne et al. (2000) and Bulkley, Myles and Pearson (2001) propose models where each of the participants may not only vote for given options or candidates but also propose new platforms. Equilibria are always in mixed strategies. They entail that the number of participants is small, and that only members with extreme preferences participate. ${ }^{4}$ The key assumptions driving the latter result are that (a) the political actors' valuation functions are concave in the distance to their ideal points and identical in shape and (b) the sensitivity of the political outcome to an actor's withdrawal is nondecreasing in the distance of the outcome from the actor's ideal point (if the median voter result applies, the outcome is unaffected by the extremeness of the preferences).

A different literature examines participation in the political process through lobbying rather than voting (Austen-Smith and Wright, 1992; Potters and van Winden, 1992; Lohmann, 1995). Here, interest groups decide whether to send costly signals to politicians in certain states of the world which politicians cannot observe. Politicians then aggregate the signals received into political outcomes. In some of the equilibria of these models, actors signal in states where their stakes are high but do not signal otherwise. Here again, "moderates" do not participate. Beniers and Swank (2003) consider endogenous committee composition in the case that the principal (such as a plenary meeting) can select members into committees and committee members choose whether to incur information costs.

In the setting where committee members self-select from the members of a parent chamber, the public good account and the strategic voting account of participation give rise to two different ways in which committees may be non-representative of the parent chamber. Both of them may be present in real-world situations. ${ }^{5}$ First, a bias can arise if the ratio of costs and benefits is

Börgers (2002) compares the normative properties of voluntary and compulsive voting when voting is costly.

Whether or not the bias is detrimental to welfare will not be addressed in this paper. 
distributed unevenly among voters. If benefits and costs are correlated with preferences over voting outcomes, individuals with particular voting intentions are drawn disproportionately into committees. As a consequence, members of the parent chamber from different ends of the preference distribution have a different likelihood of being represented in committee. Second, a committee may accurately represent the relative strength of the extremes from the preference distribution, but moderates may have a lower likelihood of being members of the committee. ${ }^{6}$ These predictions form the basis of empirical testing for the rest of the paper.

Bulkley et al. (2000) and Turner and Weninger (2003) provide empirical case studies to test the proposition that voters with more extreme preferences participate more often than moderates. Bulkley et al. use data from the British House of Lords and capture preferences by party affiliation. Members of the House of Lords affiliated to political parties are assumed to have more extreme preferences than "cross bench" peers who choose to remain outside the party structure. They find that attendance is much lower in the latter group of Lords than in the former. Turner and Weninger analyse attendance by firms from the Mid-Atlantic clam fishery in public meetings determining regulation. They find that participation is higher for firms with extreme interests, where interests are measured by an index based on observable characteristics and constructed using an economic model. They also control for a number of other characteristics.

Compared to these approaches, this paper applies a different methodology. First, it looks at participation and voting decisions simultaneously. By comparing ideal points of participants and nonparticipants predicted from the voting equation, differences in the distribution of preferences can be inspected quite conveniently. In particular, we can assess whether moderates are less well represented in committees than extremists without the need of identifying any single variable with extremeness of preferences.

Second, the model accounts for unobserved factors in the participation decision. It is easy to deal with observed determinants of participation. If, for

These forms of bias may also influence voting outcomes, depending on the particular voting rule chosen. However, the derivation of voting outcomes is not the object of this paper. 
instance, high-income countries are more likely to participate in committees and have a higher preference for stricter standards, this will be reflected in the coefficients for income. By contrast, if there are unobserved preference components inducing the country to vote for stricter standards, their presence may lead to distorted inferences unless they are incorporated in the model. We test for selection on unobservables using a Heckman-type test for correlation between the residuals of the participation and voting equations. Concerning interpretation, a correlation would suggest the presence of unobserved factors shifting the distribution of preferences over voting outcomes among actors who vote. Hence, the test for selectivity can be used to determine whether self-selection draws voters from different sides of the preference distribution into committees with different probabilities.

\section{Rules for participation and voting}

This section describes the rules for participation and voting in ILO committees. The main organ of the ILO is the International Labour Conference. It convenes once a year, in recent history always in June. It is ultimately responsible for the adoption, by qualified majority voting, of labour standards. The Conference is also responsible for the supervision of the application of ratified conventions. The Conference adopts the programme and budget of the ILO as proposed by the Governing Body, decides over amendments to the ILO Constitution and elects, every three years, the Governing Body of the ILO.

There are two different types of committees to the Conference: standing committees (such as credentials, selection, drafting and finance committees, the constitutional amendment committee, and the committee on freedom of association) and ad-hoc committees (in particular, committees for each item on the agenda of the Conference). Although the empirical analysis in this paper is based on committees drafting international labour standards only, the rules for committee decision making outlined in the following apply to all committees.

Participation in committees follows the principle of tripartism. Committees are composed of delegates from governments, trade unions (often simply called worker delegates) and employer associations (often called 
employer delegates). These groups of delegates nominate the members of committees. The nominations are then put to the Conference for approval (Standing Orders of the International Labour Conference, Article 56). Worker and employer delegates vote in a personal capacity, while government delegates are representatives. National delegations lose their right to vote when the country is more than two years behind in paying its contributions to the ILO. Otherwise, there are no formal restrictions on participation. In particular, there is no fixed number of committee seats.

Concerning nominations in the government group, the only group of delegates we will be concerned with in the empirical analysis, actual practice cannot be observed since group meetings are not held in public. However, Article 75 of the Standing Orders ${ }^{7}$ gives some indication of how governments enter committees. Governments provide the group chairperson with a list of committees they wish to be represented in. On this list, committees are ordered by the priority the government assigns to them. If the number of governments wishing to be represented in a committee is much higher than the number of delegates from other groups, governments giving a low priority to a committee may not be given a seat. In this case, they are assigned as deputy members (Article 56.4). However, given that there are a large number of committees on vastly different subjects at each session of the Conference, governments can almost ensure participation in a particular committee by giving a high priority to it. Therefore, we take it that individual governments, and not the government group as a whole, are responsible for the representation in each committee.

Article 65 of the Standing Orders regulates the procedures for voting. There is a weighting procedure which ensures that each of the three functional groups have the same weight in voting. Voting is by simple majority. Article 66 introduces a quorum rule: a vote is not valid if the number of votes cast for and against is less than two-fifths of the total voting power. Hence, abstentions do not count towards the quorum. As a consequence, the lack of quorum is a frequent voting result in committees. ${ }^{8}$

The article was deleted in 2002

(http://www.ilo.org/public/english/standards/relm/ilc/ilc90/com-sod.htm).

"Abstentions become a real weapon, more effective than negative votes for blocking a decision considered politically inexpedient" (Ghebali 1989: 184). 
Except for elections, which are held by secret ballot, there are two methods of voting in committees, namely voting by show of hands and rollcall (or record) votes. Roll-call votes are held under three conditions: (1) if the result of a vote by a show of hands is challenged (2) if requested by show of hands by at least one-fifth of the members present at the sitting, and (3) if a quorum has not been obtained in a vote by show of hands and the Chairman decides to take a repeat vote (Article 66). From the committee protocols, it appears than roll-call votes are often demanded by the losing side in a previous vote by show of hands in order to make delegates more accountable for their decisions.

Roll-call votes are not held randomly over all issues but are typically produced under a number of conditions. First, they are likely to occur when the expected outcome is close, either because of the possible lack of a quorum or because the minority believes that some delegates may change their positions in a roll-call. Second, roll-call votes are more likely on important than on minor issues. Only if the interest in the issue is high enough is it worthwhile to request a formal roll-call vote, which takes some time to be executed. Third, the roll-call votes are held after all attempts at reaching consensus on the issue, whether made during the formal proceedings of the committee or outside the committee in corridors or coffee shops, have failed. The search for consensus has been more intense during the period after 1990, as documented by the number of votes held in committees (see Boockmann, 2000: 19ff.). Together, these properties characterise the voting decisions to be considered in the following empirical analysis.

\section{The data}

The paper uses a unique collection of data on voting in ILO committees. We sampled all roll-call votes within ad-hoc committees drafting international labour standards within the time period from 1980 to 1999. The basis of the sampling procedure were the Committee Protocols, which form part of the published Record of Proceedings of the International Labour Conference. The total number of votes found is 70 .

By concentrating on votes on labour standards, we restrict attention to the most important function of the ILO. It may be argued that there is little 
distributive conflict over the formulation of labour standards because ILO conventions must be ratified by individual member states before they become legally binding. Hence, if voting produces a convention undesirable from a country's of point of view, this country can henceforth simply ignore it. However, the presence of conventions may have implications for the domestic political process. For instance, it may lend authority to certain demands for regulation (Boockmann, 2001). Therefore, we take it that governments do indeed have an interest in the contents of conventions.

The printed Record of Proceedings does not contain voting lists for the committees. Therefore, individual voting behaviour had to be taken from the hand-written protocols of the committee chairpersons, which are stored in the ILO Archives. ${ }^{9}$ The files of all committees in which roll-call votes were held were requested at the Archives for collection of the data. The hand-written voting lists consist of lists of delegates, ordered by functional groups, with voting behaviour recorded as yes, no, abstention, or absent. The lists also contain the aggregate voting results, which are published in the printed committee reports. For a number of votes, complete files were temporarily unavailable at the Archives or the protocols did not contain lists of individual delegates' voting decisions. Therefore, the total number of votes in the sample reduces to 53 .

The first thing to note about the voting data is that voting behaviour among the Worker and Employer groups is very homogenous, particularly among Worker (trade union) delegates. There is not a single case of a Worker delegate voting against the majority of delegates from this group, and, in cases where the majority did not abstain, only six per cent of trade union votes are abstentions. Among employers, less than one per cent of employer delegates voted opposite from the majority, and 17 per cent abstained when the majority voted either yes or no. Abstentions occurred, in particular, before 1990 when employers from the Eastern bloc refused to take the side of private employers from Western countries. However, even in the case of employers there is almost no variation to be explained. Therefore, we limit

Data collection took place in two steps in April, 2000, and in September, 2002, at the ILO Archives in Geneva. 
ourselves to explaining the voting results for government delegates in the following.

A second characteristic of the data is that in almost all cases, unions and employers vote differently from one another. This is due to the fact that rollcall votes are taken only if the outcome is close. Whenever unions and employers agree to a motion, there is a clear majority for it and hence, no need to take a record vote. Table 1 shows that there are only two exceptions where there was agreement between unions and employers. Since it is unclear how to code government voting behaviour in this case (see below), these two votes are omitted in the estimations.

\section{Table 1 about here}

Table A1 in the appendix lists committees in which record votes were held. The subject of the committee is identified by the name of the ILO Convention or Recommendation drafted in the committee. The number of roll-call votes held in each committee differs between zero and eight in our sample. The table also indicates the number of government delegates voting yes, no or abstaining on the issue. Finally, voting behaviour of the majority of delegates from the Worker and Employer groups is included in the last two columns of the table.

\section{Descriptive statistics}

The population of actors consists of all governments of ILO member states eligible to vote at the International Labour Conference. As mentioned earlier, governments lose the right to vote if they are in arrears with their financial contributions to the ILO. In practice, this provision is used only infrequently, hence we neglect this issue in the following. ILO membership increased from 144 in 1980 to 174 in 1998. From this, we can calculated the potential membership of committees. If all ILO members had participated in all committee roll-call votes in the sample, there would have been 8,144 votes (see table 2). 
Participation in committee voting follows a multi-stage selection process. The government of the ILO member state first decides whether to participate in the International Labour Conference at all. Second, it decides in which committees to participate and in which order to rank the requests for participation. Third, on the basis of this ranking, the Government group selects committee members. Committee membership varies over the sessions of each committee. In table 2 , we count governments being members of the committee and eligible to vote at the time the vote was taken. Fourth, even if a government is a member of a committee, it may not participate in the vote.

Due to the lack of credible exclusion restrictions, we abstract from the multi-stage character of decision-making in the estimations. Instead, we take all ILO member governments as the universe of voters and look at the decision to participate actively in the committee, i.e. to cast a vote as "yes" or "no" or to abstain.

\section{Table 3 about here}

To give a first impression of behavioural differences among governments of ILO member states, table 3 contains committee participation and voting behaviour by geographic region. Results by country are listed in the appendix (table A2). Table 3 lists absolute and relative participation rates. Absolute participation is the number of actual votes in committees (yes, no, abstention) over the number of all possible votes, i.e. the number of votes the country could have participated in, taking into account the period of ILO membership. Relative participation addresses the question whether or not committees are representative of their parent chamber, in this case the International Labour Conference. It is constructed as the ratio of absolute participation in committees to absolute participation in the parent chamber. Clearly, a government never participating in the International Labour Conference will also never be a member of a committee, and nonmembership in the committee has no effect on its representativeness with respect to the Conference (however, it affects the representativeness of the Conference with respect to ILO membership).

With respect to regional differences in participation, absolute and relative participation rates give similar results. There is a clear divide between 
industrialised and developing countries. North America and Western Europe have high participation rates in committees both in absolute and in relative terms, while the lowest participation rates are found for Eastern Europe and Latin America.

The last column of table 3 contains a voting index. To construct it, the raw data need to be transformed to account for the substance of the issue on which the vote was taken (for instance, whether the motion aimed at strengthening or weakening the standard). The procedure is based on the fact that, due to antagonistic voting behaviour of unions and employers, governments are forced to take either side or abstain on the issue. The variable VOTE, used as the dependent variable in the following, is defined as follows:

- $V O T E=1$ if the government delegate votes in the same way as Workers;

- $V O T E=-1$ if the government delegate votes in the same way as Employers;

- $V O T E=1$ if the government delegate votes opposite to Employers, with Workers abstaining;

- $V O T E=-1$ if the government delegate votes opposite to Workers, with Employers abstaining;

- $V O T E=0$ in all other cases.

The definition is based on voting relative to Workers and Employers, not directly on the choice of yes, no or abstention. Therefore, a closer examination of the subject of the votes is unnecessary. Coding votes in this way also allows for abstentions not due to indifference. This is important because, due to the quorum rule, abstentions can be used strategically to prevent the adoption of amendments. If Employers or Workers choose to abstain, a government also abstaining in the vote is coded as voting together with this group. Thus, the category where VOTE $=0$ is reserved for those cases where governments keep in the middle of Employers and Workers. In addition, if Employers (Workers) vote either yes or no and the government votes in the opposite way, with the other group abstaining, the government is coded as voting together with the group abstaining. 
The clear divide in voting behaviour between unions and employers makes the data uni-dimensional. Uni-dimensional data are ideal for testing the hypothesis that extremists participate more often because extremism can be easily observed. In effect, every state is located in the left-right dimension by the number of times it votes for or against unions (given that the state is represented in the committees at least for some votes). Thus, the voting index is constructed for each government by summing over all votes recorded for it and dividing by the number of votes. Table 3 presents averages by region of these statistics, weighted by the number of votes.

From the table, we observe huge differences in voting behaviour across geographic regions. The US and Canada, which form the North America group, have by far the lowest voting index, suggesting that they have voted three times as much with the Employer group as with the Worker group. At the other extreme, we find Eastern Europe to be a net supporter of the Workers group. This is due to the fact that half of the data are from the pre1989 period. Hence, communist governments are included in this group. Western European governments also tend to vote in favour with unions, while East Asian and, in particular, South Asian government delegates tend to vote together with employers. The other countries have more or less balanced voting records.

Comparing the voting indexes with participation rates, there does seem to be some preliminary evidence that countries with more extreme voting records in committees also participate more often. The United States and Canada have the highest participation rates and, at the same time, a rather extreme voting record. The opposite is true for governments from SubSaharan Africa or Latin America: these governments rarely vote in ILO committees, and their voting behaviour exhibits no particular tendency to either extreme. However, it is not clear whether the differences in participation are produced by preference intensities or whether they reflect the impact of covariates. In particular, European and North American governments may participate more often due to their higher resource endowment as compared to other countries. To distinguish between these alternative accounts, a multivariate analysis of committee voting is required. 


\section{Empirical methodology}

There are two equations in the model: a participation equation and a voting equation. Participation is a binary outcome. Assuming that the residuals are normally distributed, the probit model provides the appropriate estimator. In the voting decision, the dependent variable (VOTE) falls into one out of three categories (against unions, in favour of unions and abstention). Due to the coding procedure, abstentions can always be interpreted as indifference. Therefore, the categories of VOTE can be ordered by the degree of support for the union position. Under the normality assumption, the estimator is the ordered probit model.

A difficulty is that the voting decision is only observed for those ILO member states who participate and vote in the committee. If the universe of voters is total ILO membership, the sample is, therefore, a selected sample. A test for the presence of selectivity is the method proposed by Verbeek and Nijman (1992). These authors suggest the inclusion of lagged participation and using a $t$-test on the coefficient of this variable. In our case, lagged participation refers to the last vote in the previous committee, since participation decisions within committees are highly correlated. Applying the test of Verbeek and Nijman (1992) did not indicate sample selection bias. However, this evidence does not convincingly rule out selectivity. First, some countries never participate in committees (see table A1), so they do not enter the estimation of the selectivity term. Second, it may be that lagged participation is not a good indicator for overall selectivity.

Therefore, we explicitly estimate a sample selection model. The model is an extension to the ordered probit case of the bivariate probit model introduced in Van de Veen and Van Praag (1981) and Boyes et al. (1989). The equation determining selection is

$$
P_{i j}^{*}=z_{i j}{ }^{\prime} \gamma+\eta_{i j},
$$

where $P_{i j}^{*}$ is the latent propensity of country $i$ to participate in vote $j$, $\gamma_{i j}$ are characteristics and $\gamma$ are the parameters to be estimated. The equation determining voting is given as 


$$
V_{i j}^{*}=x_{i j}^{\prime} \beta+\varepsilon_{i j},
$$

where $V_{i j}^{*}$ is country $i$ s latent degree of consent with the union delegates. We assume that the errors are distributed jointly normal:

$$
\left[\begin{array}{l}
\varepsilon \\
\eta
\end{array}\right] \sim N(0, \Sigma), \quad \text { where } \Sigma=\left[\begin{array}{cc}
\sigma_{\varepsilon} & \rho \\
\rho & \sigma_{\eta}
\end{array}\right] \text {. }
$$

Using the joint normality assumption, the log likelihood function is

$$
\begin{aligned}
\log L & =\sum_{i} \sum_{j} \ln \left\{\Phi_{2}\left(-\mu_{1}-x_{i j}{ }^{\prime} \beta, z_{i j}{ }^{\prime} \gamma, \rho\right)^{n_{i j}}\right. \\
& \times\left[\Phi_{2}\left(-\mu_{2}-x_{i j}{ }^{\prime} \beta, z_{i j}{ }^{\prime} \gamma, \rho\right)-\Phi_{2}\left(-\mu_{1}-x_{i j}{ }^{\prime} \beta, z_{i j}{ }^{\prime} \gamma, \mathcal{F}\right.\right. \\
& \times\left[1-\Phi_{2}\left(-\mu_{2}-x_{i j}{ }^{\prime} \beta, z_{i j}{ }^{\prime} \gamma, \rho\right)\right]^{y_{i j}} \\
& \left.\times \Phi\left(z_{i j}{ }^{\prime} \gamma\right)^{\left(1-p_{i j}\right)}\right\},
\end{aligned}
$$

with $p_{i j}, n_{i j}, a_{i j}, y_{i j}$ being dummy variables indicating participation, voting against unions, abstentions and voting in favour of unions for country $i$ in vote $j$. $\Phi$ and $\Phi_{2}$ indicate the cumulative normal and bivariate normal c.d.f., and the $\mu$ 's are the estimated threshold values for the ordered alternatives.

The selection and voting equations are identified through restrictions on the functional form without any exclusion restrictions being technically necessary. However, identification based on functional form alone is not 
likely to lead to robust results. There is, however, a natural exclusion restriction which is also used to identify the model (see next section).

\section{Independent variables and data sources}

The variables used for $x$ and $z$ capture the costs of participation and the evaluation of possible outcomes of voting. We start by discussing the specification of the voting equation. Among the explanatory variables, partisan influences may be particularaly important. Presumably, left-wing governments tend to vote in line with unions, since they have similar constituencies and often rely on unions in their re-election strategies. Rightwing governments may have similar attachments to employers. The measure of ideology is provided by the World Bank Database of Political Institutions (Beck et al., 2001). Unlike data sources available only for industrialised countries, party positions are not derived from the study of political platforms or expert judgements but are based on nominal criteria such as "socialist" or "conservative", with information added from Derksen's internet directory of parties [http://www.electionworld.org]. The variable refers to the party of the government's central executive officer and distinguishes left-wing, rightwing, and centre parties as well as parties which do not fit into the left-right spectrum or the orientation of which is unknown. These parties may be based on ethnic divides, social class or economic sectors such as agriculture. In addition, we include a dummy for COMECON members for the years before 1990 .

table 4 bere

There may be a positive influence of democracy on voting with unions. Almost all labour and social standards include some degree of redistribution. If they redistribute wealth to a majority of citizens, democracies governments tend to vote in favour of them more than dictatorships. ${ }^{10}$ The Freedom House indicator for political freedom is used to capture this influence. Another factor possibly influencing voting behaviour is previous ratification

For the case of environmental standards, a similar argument has been made by

Congleton (1992). 
behaviour. Countries more inclined to ratify ILO conventions may have a more positive attitude towards strengthening them. The variable used is the proportion of ILO conventions ratified by each country up to the current year.

Low income countries may have particular difficulties adopting labour standards if these contain too advanced a level of regulation. These standards are useless to them since they will not be ratified. In the extreme, too advanced standards may be even detrimental for low income countries if these countries are put under pressure to ratify them. ${ }^{11}$ Seen from the side of industrialised countries, there may be the attempt to raise rivals' costs: high income countries vote in line with unions since they aim to preserve their competitive advantages by making newly adopted ILO standards tighter. We include real GDP per capita (from the Penn Tables) using dummy variables for five income brackets.

In addition, two sets of dummy variables are used in the estimations. The first group refers to countries. An indicator is used for the eight broad geographic regions listed in table 3. In one case, it was useful to combine geographic region with legal tradition: the North American group of countries is extended by all industrialised countries with Anglo-Saxon legal origin to form a separate group. The second group of dummy variables refers to subject-matter. An indicator is defined for each committee giving the subject definition of the standard formulated within the committee. These definitions are 12 broad categories such as human rights, working conditions, social security, etc. ${ }^{12}$ Finally, a dummy variable is included for each year in the data set.

Turning to the participation equation, the same independent variables determining voting behaviour should also be included here because, if countries join committees in order to influence voting, preferences over voting outcomes influence participation. Some of these variables may also directly influence participation. However, some variables may also have a

11 However, there is little evidence for external pressure to ratify standards (Boockmann, 2001), apart perhaps from the most basic standards on child labour, forced labour and civic rights.

12 See www.ilo.org/whatare/standards.htm. Health and safety standards, which are contained in working conditions in the ILO classification, form a separate category. 
direct influence on participation. For instance, delegates from countries hardly ever ratifying ILO conventions presumably have a much lower interest in participation than delegates from countries where conventions are frequently implemented. The interests of the former group of delegates may, however, be affected because other countries ratify conventions, if ratification influences countries' competitive position on world markets.

An important group of variables reflect countries' resources. Participation in a committee requires that a delegate or substitute takes part in the committee for a period of several weeks. Moreover, the delegate must be instructed or briefed on the subject of the committee by the domestic administration. All this may put too heavy a burden on the government of small and low-income countries. Two variables reflect countries resources. First, we use income as in the voting equation. Second, we use total population. This variable is excluded from the voting equation, since there is no plausible relation ex ante between population size and voting behaviour. Including it in the participation equation thus helps to identify the model beyond the functional form assumptions discussed in the previous section.

Table 4 provides the data sources for the independent variables and gives means and standard deviations, both for the full sample of ILO members used in estimation as well as for participants only. There are some conspicuous differences between voters and non-voters. On average, countries the governments of which voted in ILO committees have 117 per cent higher GDP per capita and more than tree times higher population size than other countries. They have a lower value of the political freedom index indicating more democratic institutions. They also have a 56 per cent higher likelihood of ratifying ILO conventions. Finally, with 62 per cent the share of governments with ideological provenance from either extreme of the political spectrum is also higher among voting than among non-voting governments; among the latter, only 48 per cent of governments are classified either as right and left, whereas the remaining 52 per cent are either from the political centre or non-aligned. This difference could be read to provide some prima facie evidence (in the way the findings of Bulkley et al., 2001, do for the House of Lords in the UK) in favour of the hypothesis that extremists have a higher likelihood of participation in voting. Using conventional $t$ - and $\chi^{2}$-tests, all of 
these differences between voters and non-voters are found to be statistically significant at the one per cent level.

\section{Empirical results}

In the following, we compare the results of three estimators differing in the way they take into account selectivity and the panel character of the data:

- pooled estimators for separate estimation of the voting and participation equations;

- random effects estimators, again estimating both equations separately;

- a pooled estimator of the selectivity model based on equation (4).

The pooled estimators use a covariance matrix corrected for the fact that there is more than one observation per country, allowing for dependence in each country's voting decisions. Random effects in discrete choice models create problems since they require the solution of multiple integrals. Here, a quadrature procedure is used as a numerical procedure to approximate the integrals (see Butler and Moffitt, 1980). ${ }^{13}$ Absent selectivity, all models are consistent under the assumption that the heterogeneity is orthogonal to the regressors, but the random effects model is more efficient than the pooled model if there are country-specific unobservable effects constant over time. If there is selectivity, only the third model provides consistent estimates.

Table 5 presents estimates for the participation equation. As one would expect, there are no differences between the coefficients of the pooled probit model and the joint model for voting and participation reproduced in the first and the third column, respectively. Estimations with random effects, however, produce some changes in the coefficients, as can be seen from the second column. The random effects parameters are jointly significant at any reasonable level. In general, panel estimation results in coefficients higher in absolute magnitude. In the following, however, we restrict ourselves to interpreting qualitative effects. Taking into account the standard errors of the coefficients, the number of significant coefficients is the same between pooled and random effects estimation. Standard errors estimated in the usual way are 
included in round brackets, while bootstrapped standard errors are in squared brackets. Substantially, both models lead to the same conclusions.

\section{table 5 about here}

The size of the population is highly significant in explaining governments' participation in committees. The proportion of ratified conventions also influences countries' willingness to attend committee sessions positively. The participation likelihood is significantly lower for governments of countries with low political freedom ( $=$ high levels of the freedom house index). All this confirms the descriptive evidence reported earlier. The level of GDP per capita increases participation, but only up to a limit of 10,000 US-\$. Participation among the group of countries with GDP between US- $\$ 2,000$ and 5,000 is higher than among the baseline group of poorest countries, and still larger in the third income category. Beyond that level, however, additional income has no effect on participation. Country and subject group dummies as well as year dummies are all jointly significant at the one per cent level in all estimations.

Contrary to the descriptive evidence, the party affiliation variables do not support the view that politically more extreme governments have a higher likelihood of participation. In fact, governments formed by left, centre or right political parties vote significantly less frequent in ILO committees than non-aligned governments when other independent variables are accounted for. Apparently, the effect of extremism found in table 4 is produced by intervening variables such as income or political freedom. The result that non-aligned governments participate most often is not easily interpreted, since non-aligned parties do not form a coherent group. A possible explanation is that countries where parties have formed along the traditional left-right spectrum tend to be more democratic, and this in some way interacts with the coefficient for the political freedom index. Another result is that COMECON member states in the pre-1990 period participated less often

13 To estimate the ordered probit with random effects, the "reoprob" procedure implemented in STATA by Frechette (2001) has been used. 
than other countries, which reflects the reservation with which communist countries viewed the purpose and the operation of the ILO. ${ }^{14}$

\section{table 6 about here}

Table 6 presents the results for the voting equation from the three different estimators, arranged in the same order as in table 5. Positive coefficients indicate a propensity to vote together with the Worker group. Comparing across the three different estimators, we find that both the panel and the selectivity specification change the magnitude of some of the coefficients without, however, any effects on their significance. Again, the random effects are highly significant. Using a likelihood ratio test, the pooled model with separate estimations is also rejected as compared to the selectivity model. This implies that some unobserved characteristics correlated with preferences on voting outcomes induce countries to self-select into committees.

Concerning the influence of the independent variables, there is strong support for government ideology as a determinant of voting outcomes. If the government's CEO belongs to a left-wing political party, the government is significantly more likely to vote along with the Worker group. There are no significant differences between governments formed by centre or right-wing parties or non-aligned governments. Even controlling for left party governance, COMECON member governments are more likely than others to take the sides of the Worker group.

The number of ratifications of previous ILO conventions and the degree of political freedom does not enter significantly in the voting equation. There is some evidence that countries with a higher GDP per capita are more inclined to vote together with the Employer group, clearly contradicting the “raising rivals' costs" account of ILO conventions. The effect is most significant in the highest income category. Not surprisingly, these differences are much more pronounced when we do not control for country groups (results not displayed). The country and conventions group dummies, as well as the year dummies, are again statistically significant at the one per cent level.

$14 \quad$ Alcock (1970: 182f.); Ghebali (1989). 
Taking Continental Western Europe as the reference group, the Anglo-Saxon, East Asia and South Asia dummies are all significantly negative (not reported in the table). Among the subject group dummies, a highly significant coefficient was found for conventions on social security. Arguably, governments voted least in favour of the Worker group's position in these matters because tighter standards in this area lead to higher fiscal costs, while additional labour costs produced by of other standards are largely borne by the private sector.

\section{Comparison of preferences of committee members and non- members}

A simple way to visualise how observed and unobserved selectivity affects the voting outcomes in ILO committees is obtained by comparing linear predictions from the model for participating and non-participating governments. From equation (2), government $\imath$ s predicted utility from voting together with the Worker group in vote $j$ is $\hat{V}_{i j}=x_{i j}{ }^{\prime} \hat{\beta}$. The higher this expression, the greater is the degree of consent with unions. Using this index, both voting and non-voting governments can be located relative to each other in a dimension indicating the agreement with unions or employers.

The prediction of the degree of consent with union delegates is based on the selectivity model from table 6. Due to the linearity of the prediction, the predicted values may lie anywhere on the line between $-\infty$ and $+\infty$. The estimated cutpoints from the selectivity model imply that governments with a predicted index of less than -0.373 vote together with employers, those with an index of more than 0.382 vote together with unions, and those in between abstain.

We estimate the distribution of preferences non-parametrically, using an Epanechnikov kernel with bandwidth 0.03. Figure 1 presents the estimated densities for voting and non-voting government delegates. Visual inspection suggests that the distributions differ only slightly. However, the mean index is 0.028 for voters and -0.087 for non-voters, with the difference being statistically significant at the one per cent level. ${ }^{15}$ This means that, on average,

Also, a non-parametric Mann-Whitney test rejects the hypothesis that the utility indexes for voters and non-voters are drawn from the same distributions. 
self-selection draws supporters of unions into committees to a higher degree than opponents, although the quantitative difference in the mean is small.

\section{figure 1 about here}

By contrast, the prediction that moderates are less represented in committees than extremists does not seem to be borne out by the data. If it applied, one would expect thicker tails of the distribution at both ends and a higher variance. Although the variance of the utility index is slightly higher among voters than among non-voters, ${ }^{16}$ its dispersion as measured by the range between the 10 per cent and the 90 per cent quantiles is even higher among non-voters (1.315 versus 1.298$)$. Therefore, we conclude that strategic self-selection into committees of extremists attempting to turn the balance in voting cannot be observed in our data.

\section{Conclusions}

Although the ILO is formally built on the principle of „one country-one vote“, a lack of representativeness in committees may grant some members disproportionate influence on the organisation's policies. This paper has addressed which factors determine self-selection of government delegates into ILO committees, and how selection influences the composition of committees. It is found that selection can be explained both in terms of observable characteristics (such as the number of ratifications of existing ILO conventions, population size and income) and unobservable preference components. The distribution of government delegates' predicted preferences differs slightly between delegates participating and not participating in the vote. In that sense, ILO committees are not perfectly representative of total membership preferences.

We have also provided empirical evidence bearing on the question whether, as developed recently by Osborne et al. (2000) and Bulkley et al. (2001), that voters with extreme preferences have a higher propensity to participate in voting than moderates. Previous empirical tests have relied on

16 The variances are 0.281 and 0.259 , respectively. Using the Bartlett statistic, we reject the null hypothesis that the variance is equal between voters and non-voters 
observable characteristics to proxy for preferences over voting outcomes. By simultaneously explaining voting behaviour and participation, we construct a utility index based on all observable available characteristics, as well as on unobserved determinants of participation. The results show that the distribution of delegates' predicted preferences does not have a higher density at the extremes, rejecting the theoretical model.

\section{References}

Alcock, A. (1971), History of the International Labour Organization, London: MacMillan.

Austen-Smith, D.; J.R. Wright (1992), Competitive Lobbying for a Legislator's Vote, Social Choice and Welfare, 9, 229-257.

Beck, T.; G. Clarke; A. Groff; P. Keefer; P. Walsh (2001), New Tools in Comparative Political Economy: The Database of Political Institutions, World Bank Economic Review, 15, 165-176.

Beniers, K. J.; O.H. Swank (2003), On the Composition of Committees, Tinbergen Institute Discussion Paper 2003-006/1.

Boockmann, B. (2000), Decision-Making on ILO Conventions and Recommendations: Legal Framework and Application, ZEWDokumentation No. 00-03, Mannheim.

Boockmann, B. (2001), The Ratification of ILO Conventions: A Hazard Rate Analysis, Economics and Politics, 13, 281-309.

Boockmann, B. (2003), Mixed Motives: An Empirical Analysis of ILO RollCall Voting, Constitutional Political Economy, 14, 263-285.

Börgers, T. (2002), Costly Voting, American Economic Review, forthcoming.

Boyes, W. J.; D.L. Hoffman; S.A. Low (1989), An Econometric Analysis of the Bank Credit Scoring Problem, Journal of Econometrics, 40, 3-14.

Bulkley, G.; G.D. Myles; B.P. Pearson (2001), On the Membership of Decision-Making Committees, Public Choice, 106, 1-22.

Butler, J.; R. Moffit (1982), A Computationally Efficient Quadrate Procedure for the One Factor Multinominal Probit Model, Econometrica, 50, 761764.

Congleton, R.D. (1992), Political Institutions and Pollution Control, Review of Economics and Statistics, 74, 412-421.

Diermeier, D.; T.J. Feddersen (2000), Information and Congressional Hearings, American Journal of Political Science, 44, 51-65. 
Dixit, A.; M. Olson (2000), Does Voluntary Participation Undermine the Coase Theorem?, Journal of Public Economics, 76, 309-335.

Frechette, G. (2001), Update to Random-Effects Ordered Probit (sg158.1), Stata Technical Bulletin, 61, May 2001.

Frey, B.S. (1997), The Public Choice of International Organisations, in: Mueller, D. (ed.), Perspectives on public choice, Cambridge: Cambridge University Press.

Gerling, K.; H.-P. Grüner; A. Kiel; E. Schulte (2003), Information Acquisition and Decision Making in Committees: A Survey, European Central Bank Working Paper No. 256.

Ghebali, V.-Y. (1989), The International Labor Organisation, Dordrecht: Martinus Nijhoff.

Gilligan, T.W.; K. Krehbiel (1987), Collective Decision-Making and Standing Committees: An Informational Rationale for Restrictive Amendment Procedures, Journal of Law, Economics, and Organization, 3, 287-335.

Groseclose, T.; D.C. King (2000), Committee Theories Reconsidered, in: L.C. Dodd; B.I. Oppenheimer (eds.), Congress Reconsidered, 7th Edition, Washington D.C.: Congressional Quarterly Press, .

Ledyard, J.O. (1981), The Paradox of Voting and Candidate Competition. A General Equilibrium Analysis, in: G. Hornwich and J. Quirk (eds.), Essays in Contemporary Fields of Economics, West Lafayette: Purdue University Press.

Ledyard, J.O. (1984), The Pure Theory of Large Two-Candidate Elections, Public Choice, 44, 7-41.

Lohmann, S. (1995), A Signalling Model of Competitive Political Pressures, Economics and Politics, 7, 181-205.

Officer, L.H. (1994), An Assessment of the United Nations Scale of Assessments from a Developing-Country Standpoint, Journal of International Money and Finance, 13, 415-428.

Olson, M.; R. Zeckhauser (1966), An Economic Theory of Alliances, Review of Economics and Statistics, 48, 266-279.

O'Neill, B.; B. Peleg (2000), Reconciling Power and Equality in International Organizations: A Voting Method from Rabbi Krochmal of Kremsier, Jewish Political Studies Review, 12.

Osborne, M.J.; J.S. Rosenthal; M.A. Turner (2000), Meetings with Costly Participation, American Economic Review, 90, 927-943.

Palfrey, T.R.; H. Rosenthal (1983), A Strategic Calculus of Voting, Public Choice, 41, 7-53.

Palfrey, T.R.; H. Rosenthal (1985), Voter Participation and Strategic Uncertainty, American Political Science Review, 79, 62-78. 
Potters, J.; F. van Winden (1992), Lobbying and Asymmetric Information, Public Choice, 74, 269-292.

Riker, W.H.; P.C. Ordeshook (1968), A Theory of the Calculus of Voting, American Political Science Review, 62, 25-42.

Turner, M.; Q. Weninger (2003), Meetings with Costly Participation: An Empirical Analysis, University of Toronto, Department of Economics and Institute for Policy Analysis Working Paper UT-ECIPAMTURNER-01-02.

Van de Veen, W.P.M.M.; B.M.S. Van Praag (1981), The Demand for Deductibles in Private Health Insurance: A Probit Model with Sample Selection, Joumal of Econometrics, 17, 229-252.

Verbeek, M.; T. Nijman (1992), Testing for Selectivity Bias in Panel Data Models, International Economic Review, 33, 681-703.

Weingast, B.R.; W.J. Marshall (1988), The Industrial Organization of Congress, Or, Why Legislatures, Like Firms, Are Not Organized as Markets, Journal of Political Economy, 96, 132-163.

Zamora, S. (1980), Voting in International Economic Organisations, American Journal of International Law, 74, 566-608. 
Table 1: Voting behaviour of worker and employer delegates

\begin{tabular}{lrcrc}
\hline \hline Worker & \multicolumn{3}{c}{ Employer delegates } & Total \\
delegates & no & abstention & yes & \\
\hline no & 0 & 0 & 16 & 16 \\
abstention & 0 & 1 & 3 & 4 \\
yes & 24 & 8 & 1 & 33 \\
\hline Total & 24 & 9 & 20 & 53
\end{tabular}

Note: abstentions include cases where no delegates participated in voting. 
Table 2: Participation of governments at different stages of ILO decision-making

\begin{tabular}{lc}
\hline \hline & $\begin{array}{c}\text { Number of } \\
\text { observations }\end{array}$ \\
\hline ILO membership of state & 8144 \\
Conference participation by government & 7531 \\
Committee participation by government & 3492 \\
(votes cast plus absences) & \\
$\begin{array}{l}\text { Government voting (yes, no, abstain) in } \\
\text { committee }\end{array}$ & 2290 \\
\hline \hline
\end{tabular}


Table 3: Committee participation and voting by region

\begin{tabular}{lccc}
\hline \hline Region & $\begin{array}{c}\text { absolute } \\
\text { Commitee } \\
\text { participation }\end{array}$ & $\begin{array}{c}\text { relative } \\
\text { Commitee } \\
\text { participation }\end{array}$ & $\begin{array}{c}\text { voting } \\
\text { index }\end{array}$ \\
\hline East Asia/Pacific & 0.32 & 0.39 & -0.21 \\
Eastern Europe & 0.26 & 0.29 & 0.32 \\
Latin America/Carribean & 0.15 & 0.18 & 0.03 \\
Middle East-North Africa & 0.27 & 0.27 & 0.07 \\
North America & 0.96 & 0.96 & -0.55 \\
South Asia & 0.21 & 0.21 & -0.31 \\
Sub-Saharan Africa & 0.16 & 0.17 & -0.02 \\
Western Europe & 0.76 & 0.76 & 0.16 \\
\hline Average & 0.28 & 0.30 & 0.03 \\
\hline \hline
\end{tabular}


Table 4: Descriptive statistics and data sources

\begin{tabular}{lccl}
\hline \hline Variable & Sample voters & $\begin{array}{c}\text { Sample non- } \\
\text { voters }\end{array}$ & Data Source \\
\hline Share of ratified & 0.293 & 0.186 & ILOLEX data base \\
conventions & $(0.172)$ & $(0.115)$ & \\
Real GDP per capita & 7532.2 & 3478.8 & Penn World Tables \\
& $(5541.8)$ & $(4195.1)$ & \\
Total Population & $6.77 \mathrm{e}+07$ & $1.79 \mathrm{e}+07$ & World Bank World Development \\
& $(1.87 \mathrm{e}+08)$ & $(6.6 \mathrm{e}+07)$ & Indicators (WDI) \\
Chief Executive's party: & & & \\
left & 0.326 & 0.307 & World Bank Database of Political \\
centre & 0.052 & 0.043 & Institutions \\
right & 0.291 & 0.170 & \\
Political freedom index & 2.772 & 4.368 & Freedom House \\
& $(2.130)$ & $(2.237)$ & \\
\hline \hline
\end{tabular}

Standard deviations in parentheses.

Websites from which the data may be obtained:

ILOLEX: http://www.ilo.org/ilolex/english/index.htm

Penn World Tables: http://datacentre2.chass.utoronto.ca/pwt/

World Bank World Development Indicators (WDI):

http://www.worldbank.org/data/wdi2003/index.htm

World Bank Database of Political Institutions:

http://www.worldbank.org/wbi/governance/pubs/wps2283.html

Freedom House Index: www.freedomhouse.org 
Table 5: Results for the participation equation

\begin{tabular}{|c|c|c|c|}
\hline & $\begin{array}{l}\text { Pooled } \\
\text { separate }\end{array}$ & $\begin{array}{c}\mathbf{R E} \\
\text { separate }\end{array}$ & $\begin{array}{c}\text { Pooled } \\
\text { selectivity }\end{array}$ \\
\hline \multirow[t]{2}{*}{ Total population } & 0.029 & 0.038 & 0.029 \\
\hline & $(0.008)$ & $(0.003)$ & $(0.008)$ \\
\hline \multirow[t]{2}{*}{ No. of ratifications } & 2.615 & 2.492 & 2.615 \\
\hline & $(0.630)$ & $(0.282)$ & $(0.626)$ \\
\hline \multirow{2}{*}{$2000<R G D P \leq 5000$} & 0.182 & 0.546 & 0.179 \\
\hline & $(0.171)$ & $(0.081)$ & $(0.171)$ \\
\hline \multirow[t]{2}{*}{$5000<R G D P \leq 10000$} & 0.623 & 1.344 & 0.618 \\
\hline & $(0.215)$ & $(0.105)$ & $(0.215)$ \\
\hline \multirow{2}{*}{$\begin{array}{l}10000<R G D P \leq \\
15000\end{array}$} & 0.569 & 1.169 & 0.568 \\
\hline & $(0.285)$ & $(0.140)$ & $(0.283)$ \\
\hline \multirow[t]{2}{*}{$R G D P>15000$} & 0.692 & 1.140 & 0.684 \\
\hline & $(0.309)$ & $(0.163)$ & $(0.308)$ \\
\hline \multirow[t]{2}{*}{ Left Party control } & -0.260 & -0.456 & -0.258 \\
\hline & $(0.138)$ & $(0.072)$ & $(0.137)$ \\
\hline \multirow[t]{2}{*}{ Centre Party control } & -0.503 & -0.474 & -0.494 \\
\hline & $(0.205)$ & $(0.126)$ & $(0.205)$ \\
\hline \multirow[t]{2}{*}{ Right Party control } & -0.220 & -0.435 & -0.217 \\
\hline & $(0.180)$ & $(0.085)$ & $(0.179)$ \\
\hline \multirow[t]{2}{*}{ Political freedom } & -0.112 & -0.107 & -0.112 \\
\hline & $(0.039)$ & $(0.018)$ & $(0.039)$ \\
\hline \multirow[t]{2}{*}{ COMECON dummy } & -1.414 & -1.738 & -1.414 \\
\hline & $(0.367)$ & $(0.246)$ & $(0.367)$ \\
\hline $\begin{array}{l}\text { Country group } \\
\text { dummies }\end{array}$ & YES & YES & YES \\
\hline $\begin{array}{l}\text { Convention group } \\
\text { dummies }\end{array}$ & YES & YES & YES \\
\hline Year dummies & YES & YES & YES \\
\hline Log likelihood initial & -4028.46 & -4028.46 & \\
\hline Log likelihood final & -2868.73 & -2405.32 & see table 6 \\
\hline $\begin{array}{l}\text { Number of } \\
\text { observations }\end{array}$ & 6453 & 6453 & \\
\hline $\begin{array}{l}\text { LR test for RE } \\
\text { (p-value) }\end{array}$ & & $\begin{array}{l}929.50 \\
(0.000)\end{array}$ & \\
\hline
\end{tabular}

Note: Standard errors of the coefficients for the pooled models account for clustering on countries. Coefficients significant at the five per cent level printed in bold type. 
Table 6: Results for the voting equation

\begin{tabular}{|c|c|c|c|}
\hline & Pooled & $\mathbf{R E}$ & Selectivity \\
\hline \multirow[t]{2}{*}{ No. of ratifications } & 0.201 & 0.167 & 0.466 \\
\hline & $(0.453)$ & $(0.432)$ & $(0.497)$ \\
\hline \multirow[t]{2}{*}{$2000<R G D P \leq 5000$} & -0.174 & -0.199 & -0.157 \\
\hline & $(0.156)$ & $(0.142)$ & $(0.157)$ \\
\hline \multirow{2}{*}{$5000<R G D P \leq 10000$} & -0.557 & -0.578 & -0.475 \\
\hline & $(0.189)$ & $(0.181)$ & $(0.189)$ \\
\hline \multirow{2}{*}{$\begin{array}{l}10000<R G D P \leq \\
15000\end{array}$} & -0.283 & -0.327 & -0.225 \\
\hline & $(0.226)$ & $(0.222)$ & $(0.218)$ \\
\hline \multirow[t]{2}{*}{$R G D P>15000$} & -0.603 & -0.508 & -0.509 \\
\hline & $(0.276)$ & $(0.254)$ & $(0.275)$ \\
\hline \multirow{2}{*}{ Left Party control } & 0.564 & 0.418 & 0.562 \\
\hline & $(0.153)$ & $(0.114)$ & $(0.149)$ \\
\hline \multirow[t]{2}{*}{ Centre Party control } & 0.263 & 0.090 & 0.213 \\
\hline & $(0.171)$ & $(0.184)$ & $(0.165)$ \\
\hline \multirow[t]{2}{*}{ Right Party control } & 0.013 & -0.039 & 0.003 \\
\hline & $(0.164)$ & $(0.125)$ & $(0.161)$ \\
\hline \multirow{2}{*}{ Political freedom } & -0.009 & -0.023 & -0.019 \\
\hline & $(0.032)$ & $(0.029)$ & $(0.032)$ \\
\hline \multirow[t]{2}{*}{ COMECON dummy } & 0.834 & 1.017 & 0.609 \\
\hline & $(0.191)$ & $(0.538)$ & $(0.250)$ \\
\hline $\begin{array}{l}\text { Country group } \\
\text { dummies }\end{array}$ & YES & YES & YES \\
\hline $\begin{array}{l}\text { Convention group } \\
\text { dummies }\end{array}$ & YES & YES & YES \\
\hline Year dummies & YES & YES & YES \\
\hline Log likelihood initial & -2028.64 & -2028.64 & -6068.74 \\
\hline Log likelihood final & -1857.28 & -1836.91 & -4722.78 \\
\hline $\begin{array}{l}\text { Number of } \\
\text { observations }\end{array}$ & 2044 & 2044 & 6453 \\
\hline $\begin{array}{l}\text { Uncensored } \\
\text { observations }\end{array}$ & & & 2044 \\
\hline $\begin{array}{l}\text { LR test for RE } \\
\text { (p-value) }\end{array}$ & & $\begin{array}{c}40.74 \\
(0.000)\end{array}$ & \\
\hline $\begin{array}{l}\text { LR test of } \varrho=0 \\
\text { (p-value) }\end{array}$ & & & $\begin{array}{c}6.46 \\
(0.011)\end{array}$ \\
\hline
\end{tabular}

Note: see previous table. 
Figure 1. Distribution of predicted preferences for voters and non-voters

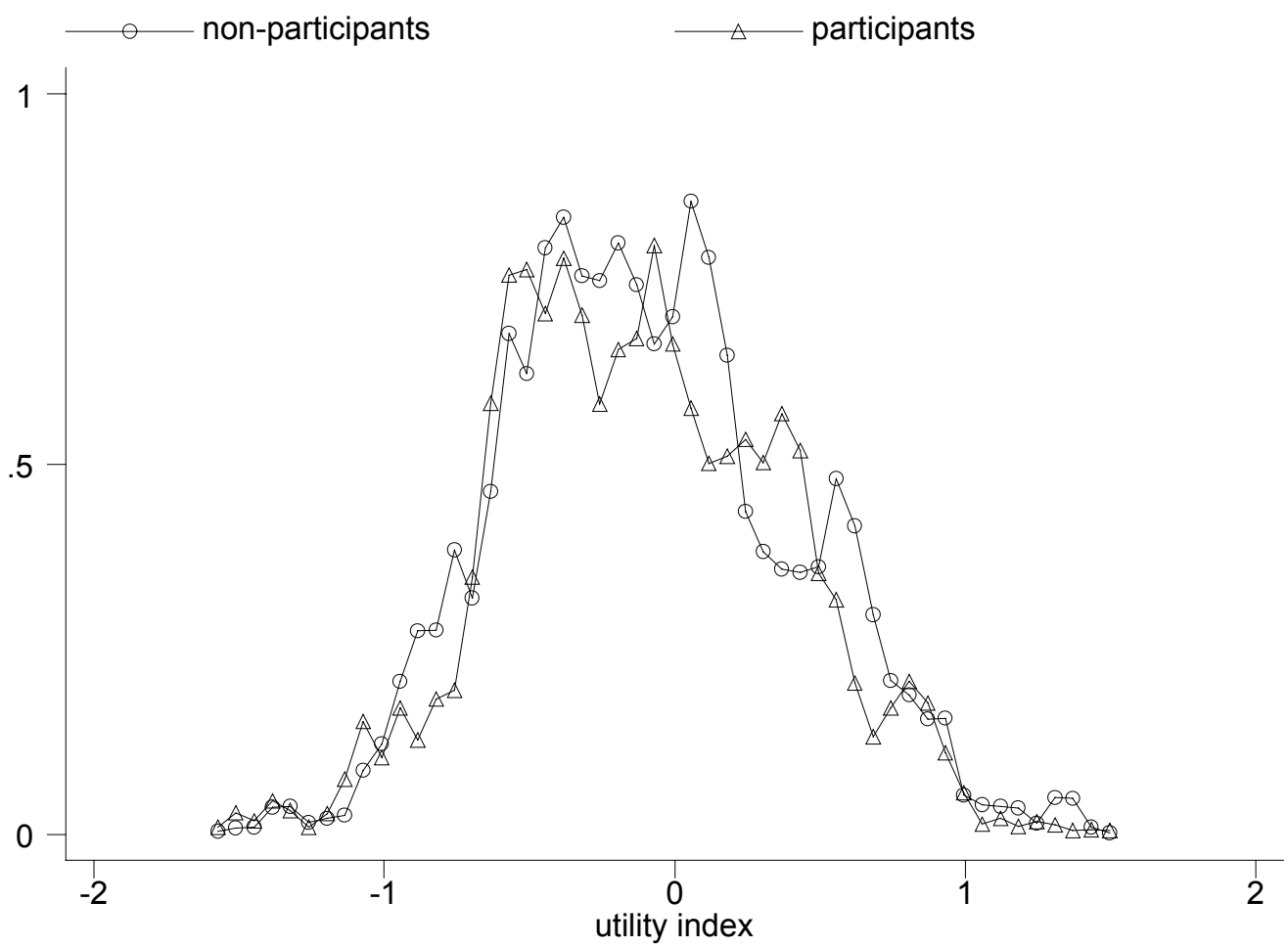


Appendix 
Table A1: Committee Record Votes 1980-1998

\begin{tabular}{|c|c|c|c|c|c|c|c|c|c|}
\hline \multirow[t]{2}{*}{$\begin{array}{r}\text { Vote } \\
\text { Number }\end{array}$} & \multirow[t]{2}{*}{ Year } & \multirow{2}{*}{$\begin{array}{l}\text { Convention; } \\
\text { Recommen- } \\
\text { dation }\end{array}$} & \multirow[t]{2}{*}{ Committee } & \multirow[t]{2}{*}{$\begin{array}{l}\text { No. of } \\
\text { RV }\end{array}$} & \multicolumn{3}{|c|}{$\begin{array}{l}\text { No. of Govern- } \\
\text { ments votes }\end{array}$} & \multirow{2}{*}{$\begin{array}{l}\text { Union } \\
\text { voting } \\
\text { behaviour }\end{array}$} & \multirow{2}{*}{$\begin{array}{l}\text { Employer } \\
\text { voting } \\
\text { behaviour }\end{array}$} \\
\hline & & & & & yes & no & abs & & \\
\hline 1 & \multirow[t]{2}{*}{1980} & \multirow[t]{2}{*}{ C154;R163 } & \multirow[t]{2}{*}{ Collective Bargaining } & \multirow[t]{2}{*}{2} & 21 & 10 & 32 & Yes & No \\
\hline 2 & & & & & 26 & 29 & 1 & Abst. & Yes \\
\hline 3 & \multirow{2}{*}{1980} & \multirow[t]{2}{*}{ C156;R165 } & \multirow[t]{2}{*}{$\begin{array}{l}\text { Workers w/ Family } \\
\text { Responsibilities }\end{array}$} & \multirow[t]{2}{*}{2} & 9 & 9 & 31 & Yes & No \\
\hline 4 & & & & & 20 & 12 & 20 & Yes & No \\
\hline 5 & \multirow{3}{*}{\begin{tabular}{|l}
5 \\
5 \\
\end{tabular}} & \multirow[t]{3}{*}{ C155;R164 } & \multirow[t]{3}{*}{ Safety and Health } & \multirow[t]{3}{*}{3} & 19 & 25 & 5 & Yes & No \\
\hline 6 & & & & & 12 & 23 & 15 & Yes & No \\
\hline 7 & & & & & 26 & 16 & 2 & Yes & No \\
\hline 8 & 1981 & C154;R163 & Collective Bargaining & 1 & 9 & 17 & 3 & No & Yes \\
\hline 9 & \multirow[t]{2}{*}{1981} & \multirow[t]{2}{*}{ C156;R165 } & \multirow[t]{2}{*}{$\begin{array}{l}\text { Workers w/ Family } \\
\text { Responsibilities. }\end{array}$} & \multirow[t]{2}{*}{2} & 8 & 5 & 21 & Yes & Abst. \\
\hline \multirow[t]{2}{*}{10} & & & & & 6 & 31 & 5 & No & Yes \\
\hline & 1981 & C155;R164 & Safety and Health & 2 & & & & & \\
\hline 11 & 1981 & C157 & $\begin{array}{l}\text { Social Security of Migrant } \\
\text { Workers (Convention no. } \\
157)\end{array}$ & 1 & 18 & 22 & 3 & Yes & Yes \\
\hline 12 & 1981 & C158;R166 & Termination of Employment & 1 & 20 & 6 & 14 & Abst. & Yes \\
\hline 13 & & & & & 18 & 2 & 19 & Yes & No \\
\hline 14 & 1982 & C157 & $\begin{array}{l}\text { Social Security of Migrant } \\
\text { Workers (Convention no. } \\
157 \text { ) }\end{array}$ & 1 & 17 & 29 & 1 & No & Yes \\
\hline & 1982 & C158;R166 & Termination of Employment & 1 & & & & & \\
\hline 15 & 1983 & C159;R168 & Vocational Rehabilitation & 1 & 16 & 14 & 8 & Yes & No \\
\hline & 1983 & R169 & Employment Policy & 1 & & & & & \\
\hline & 1984 & R169 & Employment Policy & 2 & & & & & \\
\hline 16 & 1984 & C161;R171 & Occupational Health Services & 6 & 5 & 38 & 2 & No & Yes \\
\hline 17 & & & & & 24 & 9 & 8 & Yes & No \\
\hline 18 & & & & & 27 & 8 & 10 & Yes & No \\
\hline 19 & & & & & 20 & 20 & 5 & Yes & No \\
\hline 20 & & & & & 18 & 18 & 2 & Yes & No \\
\hline 21 & & & & & 14 & 17 & 2 & Yes & No \\
\hline 22 & 1985 & C161;R171 & Occupational Health Services & 3 & 25 & 8 & 7 & No & Yes \\
\hline 23 & 1985 & C160;R170 & Convention $n^{\circ} 63$ & 1 & 14 & 19 & 3 & Yes & No \\
\hline 24 & 1985 & C162;R172 & Asbestos & 4 & 6 & 13 & 10 & Yes & No \\
\hline 25 & & & & & 10 & 4 & 16 & Yes & Abst. \\
\hline 26 & & & & & 6 & 0 & 26 & Yes & Abst. \\
\hline 27 & & & & & 17 & 4 & 8 & Yes & $\mathrm{No}$ \\
\hline 28 & 1986 & C162;R172 & Asbestos & 8 & 18 & 8 & 20 & Yes & No \\
\hline 29 & & & & & 18 & 8 & 20 & Yes & No \\
\hline 30 & & & & & 10 & 0 & 35 & non-part. & Abst. \\
\hline 31 & & & & & 10 & 0 & 35 & Yes & Abst. \\
\hline 32 & & & & & 21 & 0 & 38 & Yes & Abst. \\
\hline
\end{tabular}


Table A1: Committee Record Votes 1980-1998 (continued)

\begin{tabular}{|c|c|c|c|c|c|c|c|c|c|}
\hline \multirow[t]{2}{*}{$\begin{array}{r}\text { Vote } \\
\text { Number }\end{array}$} & \multirow[t]{2}{*}{ Year } & \multirow{2}{*}{$\begin{array}{l}\text { Convention; } \\
\text { Recommen- } \\
\text { dation }\end{array}$} & \multirow[t]{2}{*}{ Committee } & \multirow[t]{2}{*}{$\begin{array}{l}\text { No. of } \\
\text { RV }\end{array}$} & \multicolumn{3}{|c|}{$\begin{array}{l}\text { No. of Govern- } \\
\text { ments votes }\end{array}$} & \multirow{2}{*}{$\begin{array}{l}\text { Union } \\
\text { voting } \\
\text { behaviour }\end{array}$} & \multirow{2}{*}{$\begin{array}{l}\text { Employer } \\
\text { voting } \\
\text { behaviour }\end{array}$} \\
\hline & & & & & yes & no & abs & & \\
\hline 33 & & & & & 19 & 19 & 3 & No & Yes \\
\hline 34 & & & & & 19 & 19 & 3 & No & Yes \\
\hline 35 & & & & & 21 & 0 & 38 & Yes & Abst. \\
\hline 36 & \multirow[t]{2}{*}{1987} & \multirow[t]{2}{*}{ C168;R176 } & \multirow[t]{2}{*}{$\begin{array}{l}\text { Employment \& Social } \\
\text { Security }\end{array}$} & \multirow[t]{2}{*}{2} & 15 & 23 & 5 & Yes & \\
\hline 37 & & & & & 13 & 0 & 31 & Yes & Abst. \\
\hline 38 & 1988 & C168;R176 & $\begin{array}{l}\text { Employment \& Social } \\
\text { Security }\end{array}$ & 1 & & & & & \\
\hline 39 & \multirow[t]{2}{*}{1988} & \multirow[t]{2}{*}{ C169 } & \multirow[t]{2}{*}{ Convention No. 107} & \multirow[t]{2}{*}{2} & 7 & 14 & 4 & Yes & No \\
\hline 40 & & & & & 9 & 12 & 4 & Yes & No \\
\hline 41 & \multirow[t]{2}{*}{1989} & \multirow[t]{2}{*}{ C169 } & \multirow[t]{2}{*}{ Convention No. 107} & \multirow[t]{2}{*}{2} & 13 & 13 & 0 & Yes & No \\
\hline 42 & & & & & 9 & 11 & 6 & No & Yes \\
\hline 43 & \multirow[t]{2}{*}{1989} & \multirow{2}{*}{ C171;R178 } & \multirow[t]{2}{*}{ Night Work } & \multirow[t]{2}{*}{3} & 20 & 19 & 13 & Yes & No \\
\hline 44 & & & & & 26 & 19 & 9 & No & Yes \\
\hline \multirow[t]{2}{*}{45} & 1991 & C173;R180 & Workers`Claims & 1 & 11 & 5 & 37 & Abst. & Yes \\
\hline & 1991 & C172;R179 & Hotels and Restaurants & 7 & & & & & \\
\hline 46 & 1995 & C176;R183 & Safety and Health in Mines & 1 & 14 & 27 & 12 & No & Yes \\
\hline \multirow[t]{2}{*}{47} & 1995 & C177;R184 & Home Work & 1 & 21 & 28 & 2 & No & Yes \\
\hline & 1997 & C181;R189 & $\begin{array}{l}\text { Private Employment } \\
\text { Agencies }\end{array}$ & 1 & & & & & \\
\hline 48 & \multirow[t]{3}{*}{1997} & \multirow{3}{*}{$\begin{array}{l}\text { no standard } \\
\text { adopted }\end{array}$} & \multirow[t]{3}{*}{ Contract Labour } & \multirow[t]{3}{*}{3} & 29 & 22 & 8 & Yes & Non-part. \\
\hline 49 & & & & & 14 & 11 & 26 & Yes & No \\
\hline 50 & & & & & 17 & 32 & 12 & No & Yes \\
\hline 51 & \multirow[t]{3}{*}{1998} & no standard & Contract Labour & 3 & 7 & 35 & 7 & No & Yes \\
\hline 52 & & adopted & & & 13 & 27 & 3 & No & Yes \\
\hline 53 & & & & & 8 & 29 & 2 & No & Yes \\
\hline
\end{tabular}

Note: shaded entries refer to committee votes which could not be retrieved. Committees not taking at least one record vote are omitted from the table. 
Table A2: Voting and participation in ILO committees

\begin{tabular}{|c|c|c|c|c|c|c|c|c|}
\hline Country & $\begin{array}{c}\text { Partici- } \\
\text { pation } \\
\text { Ratio }\end{array}$ & $\begin{array}{l}\text { Voting } \\
\text { Index }\end{array}$ & Country & $\begin{array}{c}\text { Partici- } \\
\text { pation } \\
\text { Ratio }\end{array}$ & $\begin{array}{l}\text { Voting } \\
\text { Index }\end{array}$ & Country & $\begin{array}{c}\text { Partici- } \\
\text { pation } \\
\text { Ratio }\end{array}$ & $\begin{array}{l}\text { Voting } \\
\text { Index }\end{array}$ \\
\hline Sweden & 1.00 & 0.69 & Hungary & 0.61 & 0.35 & Malta & 0.29 & 0.27 \\
\hline Norway & 1.00 & 0.57 & Cyprus & 0.61 & -0.55 & Egypt & 0.29 & 0.13 \\
\hline Australia & 1.00 & -0.24 & Zimbabwe & 0.59 & 0.27 & Saudi Arabia & 0.27 & 0.21 \\
\hline Finland & 0.98 & 0.68 & Kenya & 0.59 & -0.37 & the Congo & 0.27 & -0.29 \\
\hline Denmark & 0.98 & 0.38 & Luxembourg & 0.57 & 0.10 & Cameroon & 0.27 & -0.43 \\
\hline US & 0.98 & -0.54 & Malaysia & 0.53 & -0.15 & Algeria & 0.25 & 0.77 \\
\hline Japan & 0.98 & -0.64 & New Zealand & 0.53 & -0.22 & Poland & 0.25 & 0.69 \\
\hline Spain & 0.96 & 0.29 & Philippines & 0.49 & 0.44 & Lesotho & 0.25 & 0.00 \\
\hline Netherlands & 0.96 & 0.06 & Argentina & 0.47 & 0.00 & Panama & 0.24 & 0.58 \\
\hline Portugal & 0.94 & 0.31 & Botswana & 0.45 & 0.22 & Iran & 0.24 & 0.42 \\
\hline India & 0.94 & -0.33 & Russian Fed. & 0.44 & -0.75 & Malawi & 0.24 & -0.75 \\
\hline Canada & 0.94 & -0.56 & Angola & 0.43 & 0.68 & Senegal & 0.22 & 0.91 \\
\hline France & 0.92 & -0.17 & Swaziland & 0.43 & -0.27 & Bulgaria & 0.22 & 0.55 \\
\hline $\begin{array}{l}\text { United } \\
\text { Kingdom }\end{array}$ & 0.92 & -0.32 & Kuwait & 0.43 & -0.41 & Chile & 0.22 & 0.09 \\
\hline Austria & 0.88 & 0.29 & GDR & 0.40 & 0.33 & the Niger & 0.20 & 0.01 \\
\hline South Africa & 0.88 & 0.86 & Iraq & 0.39 & 0.15 & $\begin{array}{l}\text { Czechoslova } \\
\text { kia }\end{array}$ & 0.19 & 0.63 \\
\hline Switzerland & 0.84 & -0.53 & Uganda & 0.39 & -0.35 & Peru & 0.18 & 0.00 \\
\hline USSR & 0.84 & 0.53 & Morocco & 0.39 & -0.60 & Suriname & 0.18 & 0.00 \\
\hline Belgium & 0.78 & 0.30 & Colombia & 0.37 & 0.16 & Tanzania & 0.18 & -0.33 \\
\hline Italy & 0.78 & 0.30 & Indonesia & 0.37 & -0.26 & Qatar & 0.16 & 0.25 \\
\hline Slovakia & 0.75 & 0.83 & $\begin{array}{l}\text { Papua New } \\
\text { Guinea }\end{array}$ & 0.37 & -0.26 & $\begin{array}{l}\text { Central } \\
\text { African } \\
\text { Republic }\end{array}$ & 0.16 & 0.13 \\
\hline $\begin{array}{l}\text { Czech } \\
\text { Republic }\end{array}$ & 0.75 & 0.00 & Côte d'Ivoire & 0.35 & -0.11 & $\begin{array}{l}\text { United Arab } \\
\text { Emirates }\end{array}$ & 0.16 & -0.25 \\
\hline Greece & 0.75 & -0.13 & Nigeria & 0.35 & -0.44 & the Sudan & 0.16 & -0.38 \\
\hline Mexico & 0.73 & 0.35 & Lithuania & 0.33 & 1.00 & Namibia & 0.14 & 0.43 \\
\hline $\begin{array}{l}\text { Fed. Rep. of } \\
\text { Germany }\end{array}$ & 0.73 & 0.22 & Tunisia & 0.33 & 0.12 & $\begin{array}{l}\text { Trinidad and } \\
\text { Tobago }\end{array}$ & 0.14 & 0.43 \\
\hline China & 0.71 & 0.08 & South Korea & 0.33 & 0.00 & Mali & 0.14 & 0.29 \\
\hline Brazil & 0.69 & -0.09 & Venezuela & 0.33 & -0.24 & Rwanda & 0.14 & -0.14 \\
\hline Ireland & 0.69 & -0.20 & Libya & 0.31 & 0.38 & Liberia & 0.14 & -0.29 \\
\hline Turkey & 0.67 & -0.26 & Uruguay & 0.31 & -0.63 & Oman & 0.13 & 1.00 \\
\hline
\end{tabular}


Table A2: Voting and Participation in ILO Committees (continued)

\begin{tabular}{|c|c|c|c|c|c|c|c|c|}
\hline Country & $\begin{array}{c}\text { Partici- } \\
\text { pation } \\
\text { Ratio }\end{array}$ & $\begin{array}{l}\text { Voting } \\
\text { Index }\end{array}$ & Country & $\begin{array}{c}\text { Partici- } \\
\text { pation } \\
\text { Ratio }\end{array}$ & $\begin{array}{l}\text { Voting } \\
\text { Index }\end{array}$ & Country & $\begin{array}{c}\text { Partici- } \\
\text { pation } \\
\text { Ratio }\end{array}$ & $\begin{array}{l}\text { Voting } \\
\text { Index }\end{array}$ \\
\hline Syria & 0.12 & 0.67 & Byelorussia & 0.05 & 1.00 & Croatia & 0.00 & \\
\hline Nicaragua & 0.12 & 0.50 & $\begin{array}{l}\text { Yemen } \\
\text { (North) }\end{array}$ & 0.04 & -1.00 & Cuba & 0.00 & \\
\hline Ethiopia & 0.12 & 0.33 & Afghanistan & 0.04 & 1.00 & Djibouti & 0.00 & \\
\hline Burundi & 0.12 & -0.17 & Benin & 0.04 & 1.00 & Dominica & 0.00 & \\
\hline Ecuador & 0.12 & -0.17 & $\begin{array}{l}\text { Dominican } \\
\text { Republic }\end{array}$ & 0.04 & 1.00 & $\begin{array}{l}\text { Equatorial } \\
\text { Guinea }\end{array}$ & 0.00 & \\
\hline Honduras & 0.12 & -0.33 & Costa Rica & 0.04 & 0.50 & Eritrea & 0.00 & \\
\hline Thailand & 0.12 & -0.50 & Mauritius & 0.04 & 0.50 & Georgia & 0.00 & \\
\hline Pakistan & 0.12 & -0.83 & Cape Verde & 0.04 & -0.50 & Ghana & 0.00 & \\
\hline Estonia & 0.11 & 1.00 & Barbados & 0.04 & -1.00 & Grenada & 0.00 & \\
\hline Slovenia & 0.11 & -1.00 & Lebanon & 0.04 & -1.00 & $\begin{array}{l}\text { Guinea- } \\
\text { Bissau }\end{array}$ & 0.00 & \\
\hline Burkina Faso & 0.10 & 1.00 & Saint Lucia & 0.04 & -1.00 & Iceland & 0.00 & \\
\hline Ukraine & 0.10 & 0.80 & Singapore & 0.04 & -1.00 & Israel & 0.00 & \\
\hline Gabon & 0.10 & 0.00 & $\begin{array}{l}\begin{array}{l}\text { Yugoslavia } \\
\text { (pre-1991) }\end{array} \\
\end{array}$ & 0.02 & 1.00 & Kazakhstan & 0.00 & \\
\hline Jamaica & 0.10 & -0.20 & Guatemala & 0.02 & 1.00 & Kyrgyzstan & 0.00 & \\
\hline Bahrain & 0.10 & -0.60 & Haiti & 0.02 & 1.00 & Laos & 0.00 & \\
\hline Guyana & 0.08 & 0.50 & Mongolia & 0.02 & 1.00 & Latvia & 0.00 & \\
\hline Bangladesh & 0.08 & -0.50 & Jordan & 0.02 & 0.00 & Macedonia & 0.00 & \\
\hline Bolivia & 0.08 & -0.75 & Madagascar & 0.02 & 0.00 & Moldova & 0.00 & \\
\hline Fiji & 0.08 & -0.75 & Mozambique & 0.02 & 0.00 & Nepal & 0.00 & \\
\hline El Salvador & 0.08 & -1.00 & Seychelles & 0.02 & 0.00 & Paraguay & 0.00 & \\
\hline $\begin{array}{l}\text { Antigua and } \\
\text { Barbuda }\end{array}$ & 0.07 & 0.33 & Guinea & 0.02 & -1.00 & $\begin{array}{l}\text { Saint Kitts } \\
\text { and Nevis }\end{array}$ & 0.00 & \\
\hline Belize & 0.06 & 1.00 & Sierra Leone & 0.02 & -1.00 & Saint Vincent & 0.00 & \\
\hline Mauritania & 0.06 & 1.00 & Albania & 0.00 & & San Marino & 0.00 & \\
\hline Romania & 0.06 & 1.00 & Armenia & 0.00 & & $\begin{array}{l}\text { Sao Tome } \\
\text { and Principe }\end{array}$ & 0.00 & \\
\hline Sri Lanka & 0.06 & 0.33 & Azerbaijan & 0.00 & & $\begin{array}{l}\text { Solomon } \\
\text { Islands }\end{array}$ & 0.00 & \\
\hline Myanmar & 0.06 & -0.33 & Belarus & 0.00 & & Tajikistan & 0.00 & \\
\hline Zambia & 0.06 & -0.33 & $\begin{array}{l}\text { Bosnia and } \\
\text { Herzegovina }\end{array}$ & 0.00 & & the Bahamas & 0.00 & \\
\hline Somalia & 0.06 & -1.00 & Cambodia & 0.00 & & the Comoros & 0.00 & \\
\hline $\begin{array}{l}\text { Congo } \\
\text { (Dem.Rep.) }\end{array}$ & 0.06 & -0.33 & Chad & 0.00 & & the Gambia & 0.00 & \\
\hline
\end{tabular}


Table A2: Voting and Participation in ILO Committees (continued)

\begin{tabular}{|l|c|l|l|r|l|l|c|c|}
\hline Country & $\begin{array}{c}\text { Partici- } \\
\text { pation } \\
\text { Ratio }\end{array}$ & $\begin{array}{c}\text { Voting } \\
\text { Index }\end{array}$ & Country & $\begin{array}{c}\text { Partici- } \\
\text { pation } \\
\text { Ratio }\end{array}$ & $\begin{array}{c}\text { Voting } \\
\text { Index }\end{array}$ & Country & $\begin{array}{c}\text { Partici- } \\
\text { pation } \\
\text { Ratio }\end{array}$ & $\begin{array}{c}\text { Voting } \\
\text { Index }\end{array}$ \\
\hline Togo & 0.00 & & Viet Nam & 0.00 & & $\begin{array}{c}\text { Yugoslavia } \\
\text { (post-1991) }\end{array}$ & 0.00 & \\
\hline Turkmenistan & 0.00 & & Yemen & 0.00 & & & & \\
\hline Uzbekistan & 0.00 & & $\begin{array}{l}\text { Yemen } \\
\text { (South) }\end{array}$ & 0.00 & & & & \\
\hline
\end{tabular}

